\title{
Exploitation and trade of Australian seahorses, pipehorses, sea dragons and pipefishes (Family Syngnathidae)
}

\author{
Keith M. Martin-Smith and Amanda C.J. Vincent
}

\begin{abstract}
Seahorses and their syngnathid relatives have provided a focus for efforts to ensure sustainable use of marine resources, with new international trade controls (CITES Appendix II) implemented in May 2004. We demonstrate how a study of international trade can be used to assess relative levels of threat and set domestic research and conservation priorities. Australia has remarkably high syngnathid biodiversity with at least 14 seahorse species, two endemic sea dragon species, and 90 species of pipefishes and pipehorses found in its territorial waters. Our objectives were to quantify species, trade routes, volumes, values and temporal trends in syngnathid trade to and from Australia. We found that Australia is probably the major global supplier of dried pipehorses Solegnathus spp.. These fishes, including at least one endemic species, are sourced from trawl bycatch and comprise Australia's largest syngnathid export, by
\end{abstract}

both volume and value. Research is urgently needed to evaluate the impacts and sustainability of trawling on pipehorse populations. Australia is also the sole supplier of two sea dragon species, Phycodurus eques and Phyllopteryx taeniolatus, for the live aquarium trade. Although lucrative, the number of wild-caught individuals involved in this trade was relatively low and probably of low conservation risk relative to habitat loss. Exports of seahorses and other pipefish species, and imports of all syngnathid species, are minor on a global scale, although the burgeoning aquaculture industry for seahorses requires careful evaluation for its potential impacts on wild populations.

Keywords Aquaculture, aquarium, bycatch, exports, imports, pipefish, pipehorse, sea dragon, Syngnathidae, traditional medicine.

\section{Introduction}

The conservation status of seahorses and other syngnathids (pipehorses, sea dragons and pipefishes) have been the focus of increasing concern since the mid 1990s, both in their own right and as flagship species for broader marine conservation issues (Vincent, 1996; Foster \& Vincent, 2004). These fishes are affected by direct overexploitation, incidental capture by non-selective fishing methods, and degradation of their marine habitats. They are also traded internationally in dried form for traditional medicine and curios and alive for aquarium display (Vincent, 1996). Concerns over unsustainable levels of exploitation led CITES to add all seahorse species to Appendix II in November 2002, with implementation on 15 May 2004. Seahorses, basking sharks and

\footnotetext{
Keith M. Martin-Smith ${ }^{1}$ (Corresponding author) and Amanda C.J. Vincent ${ }^{2}$ Project Seahorse, Department of Biology, McGill University, 1205 Avenue Dr. Penfield, Montréal, Québec H3A 1B1, Canada. E-mail keith.martinsmith@utas.edu.au

${ }^{1}$ Current address: Project Seahorse, School of Zoology, University of Tasmania, Private Bag 05, Hobart, Tasmania 7001, Australia.

${ }^{2}$ Current address: Project Seahorse, Fisheries Centre, University of British Columbia, 2204 Main Mall, Vancouver V6T 1Z4, Canada.
}

Received 20 July 2004. Revision requested 14 January 2005 Accepted 10 June 2005. First published online 19 January 2006. whale sharks were the first marine fish species of commercial importance to be brought under CITES trade controls. All subsequent trade in these species among Parties to CITES must demonstrate that the trade does not threaten wild populations.

Australia has the highest recorded syngnathid diversity of any country, with an estimated $25-37 \%$ of the world's species (Dawson, 1985; Lourie et al., 1999; Kuiter, 2000, 2003), although taxonomic uncertainties remain. Using the standard taxonomy adopted by IUCN at least 14 species of seahorse Hippocampus occur in Australian territorial waters (Lourie et al., 1999; Kuiter, 2003), with a much higher tally possible (Kuiter, 2000). A further 92 species of pipefish, pipehorse and sea dragon in 38 genera were recognized from Australian waters by Dawson (1985) with other authors estimating up to 120 species (Kuiter, 2000; Pogonoski et al., 2002). Levels of endemicity are also high with c. $25 \%$ of syngnathid genera and $20 \%$ of species known only from Australian waters (Dawson, 1985; Kuiter, 2000; Pogonoski et al., 2002). Australia's importance for syngnathid biodiversity probably arises from its historical isolation, long coastlines $(26,000 \mathrm{~km})$ extending over extensive latitude $(3,700 \mathrm{~km})$ and longitude $(4,000 \mathrm{~km})$, and great diversity of coastal habitats, including 17 demersal marine bioregions (IMCRA, 1998). 
Many Australian syngnathids are considered globally threatened on the basis of declining populations (IUCN, 2004; Table 1). The status of 38 Australian syngnathid species has also been assessed (Pogonoski et al., 2002) for national waters only (Table 1$)$. Such evaluations may represent neither the full threat nor the status of nonendemic species. For example, some seahorses that are little exploited off northern Australia, even in trawl bycatch (Stobutzki et al., 2001), are heavily fished and traded in other parts of the Indo-Pacific (H. kelloggi, H. kuda, H. spinossimus and H. trimaculatus); Australian populations may provide a refuge for such species.

Biology of wild syngnathids has been well studied in Australia in comparison to elsewhere (Steffe et al., 1989; Kendrick \& Hyndes, 2003; Takahashi et al., 2003; references in Foster \& Vincent, 2004). Australia has also led the way in ex situ studies of syngnathids (Payne et al., 1998; Payne \& Rippingale, 2000; Adams et al., 2001), partly during the development of commercial seahorse aquaculture ventures. However, the length of the coastline and diversity of the syngnathid fauna means that large gaps in our knowledge remain.

Syngnathids, particularly seahorses and sea dragons, enjoy a high profile in Australia as conservation icons and aquaculture products. Two Australian states, Victoria and South Australia, have syngnathids as their marine emblems, and a range of community initiatives focus on syngnathids (e.g. DragonSearch, 2005). At least four commercial aquaculture ventures were also established over 1996-2002, culturing local and exotic species, primarily for the home aquarium trade. The role of Australia as a centre of syngnathid diversity, aquaculture development and a potential refuge for some heavilyexploited species makes it important to investigate syngnathid trade to (1) determine which species are or have been exploited in Australia, (2) assess domestic uses of syngnathids, and (3) estimate import and export routes, volumes and values of syngnathids in trade.

Table 1 Global and Australian Red List status of all Australian syngnathid species on the global Red List (IUCN, 2004) and other species known to have been exploited in the period 1996-2002.

\begin{tabular}{|c|c|c|c|}
\hline Species $^{1}$ & Common names & Global Red List status (criteria) ${ }^{2}$ & Australian Red List status ${ }^{3}$ \\
\hline Doryrhamphus dactyliophorus & Banded/ringed pipefish & DD & \\
\hline Heraldia nocturna* & Upside-down pipefish & & \\
\hline Hippocampus abdominalis & Big-bellied/pot-bellied seahorse & $\mathrm{VU}(\mathrm{A} 2 \mathrm{~d})$ & [LR: cd] \\
\hline Hippocampus angustus* & Narrow-bellied seahorse & DD & $\mathrm{DD}$ \\
\hline Hippocampus bargibanti & Pygmy seahorse & $\mathrm{DD}$ & $\mathrm{DD}$ \\
\hline Hippocampus breviceps* & Short-snouted/short-headed seahorse & DD & DD \\
\hline Hippocampus fisheri & Fisher's seahorse & $\mathrm{DD}$ & [DD] \\
\hline Hippocampus kelloggi & Great/Kellogg's seahorse & $\mathrm{DD}$ & [DD] \\
\hline Hippocampus kuda & Yellow, spotted or estuary seahorse & $\mathrm{VU}(\mathrm{A} 4 \mathrm{~cd})$ & [DD] \\
\hline Hippocampus minotaur* & Bullneck seahorse & $\mathrm{DD}$ & $\mathrm{DD}$ \\
\hline Hippocampus spinosissimus & Hedgehog seahorse & VU (A4cd) & [LR: nt] \\
\hline Hippocampus subelongatus* & West Australian seahorse & $\mathrm{DD}$ & [DD] \\
\hline Hippocampus trimaculatus & Three-spot/low-crowned seahorse & $\mathrm{VU}(\mathrm{A} 4 \mathrm{~cd})$ & [LR: nt] \\
\hline Hippocampus whitei* & White's/Sydney seahorse & $\mathrm{DD}$ & $\mathrm{DD}$ \\
\hline Hippocampus zebra* & Zebra seahorse & $\mathrm{DD}$ & $\mathrm{DD}$ \\
\hline Phycodurus eques* & Leafy seadragon & $\mathrm{DD}$ & LR: cd \\
\hline Phyllopteryx taeniolatus* & Weedy seadragon & $\mathrm{DD}$ & LR: cd \\
\hline Solegnathus dunckeri* & Duncker's/red-and-gold pipehorse & $\mathrm{VU}(\mathrm{A} 1 \mathrm{~d}+2 \mathrm{~d})$ & $\mathrm{DD}$ \\
\hline Solegnathus hardwickii & Hardwick's pipehorse & $\mathrm{VU}(\mathrm{A} 1 \mathrm{~d}+2 \mathrm{~d})$ & $\mathrm{DD}$ \\
\hline Solegnathus lettiensis & Günther's pipehorse & $\mathrm{VU}(\mathrm{A} 2 \mathrm{~d})$ & $\mathrm{DD}$ \\
\hline Solegnathus robutus* & Robust pipehorse & $\mathrm{VU}(\mathrm{A} 2 \mathrm{~d})$ & $\mathrm{DD}$ \\
\hline Solegnathus spinosissimus & Spiny pipehorse/spiny seadragon & $\mathrm{VU}(\mathrm{A} 1 \mathrm{~d}+2 \mathrm{~d})$ & $\mathrm{DD}$ \\
\hline Stigmatopora argus* & Spotted pipefish & & \\
\hline Stipecampus cristatus* & Ring-backed pipefish & & \\
\hline Syngnathoides biaculeatus & Double-ended pipefish & DD & $\mathrm{DD}$ \\
\hline Vanacampus margaritifer* & Mother-of-pearl pipefish & & \\
\hline Vanacampus phillipi* & Port Phillip pipefish & & \\
\hline
\end{tabular}

${ }^{1}$ Using taxonomy adopted by IUCN, i.e. Lourie et al., 1999. *Endemic species

${ }^{2}$ DD, Data Deficient, VU, Vulnerable. For an explanation of criteria, see IUCN (2001); all categorizations as Vulnerable are based on criteria A, which refers to reduction in population size of some form.

${ }^{3}$ From Pogonoski et al. (2002). The taxonomy was not the same as that used by IUCN (2004); assessments of synonymous species are given in parentheses. LR: cd, Lower Risk: conservation dependent; LR: nt, Lower Risk: near threatened (IUCN, 1994). 
These data are required to assess the threat posed by syngnathid trade and set research and conservation priorities.

\section{Methods}

\section{Data sources}

We obtained information on syngnathids in Australia using a variety of methods: (1) published information from government agencies and interviews with staff $(\mathrm{n}=12)$; (2) published information and interviews with staff of non-governmental organizations $(n=5)$, commercial organizations $(n=3)$, syngnathid researchers $(n=4)$, and others $(n=2)$; (3) interviews with traditional Chinese medicine (TCM) retailers $(n=10)$, aquarium collectors/aquaculturists $(n=6)$ and aquarium retailers $(\mathrm{n}=29)$; (4) published information from Customs agencies of other countries; (5) published and unpublished information from Project Seahorse trade surveys in other parts of the world (Vincent, 1996). We endeavoured to validate our estimates through the use of multiple sources and internal consistency checks. We decided on survey locations and number of interviewees using historical knowledge of Australian trade (Vincent, 1996) and on information provided by other people, as detailed above.

Our trade surveys in TCM shops took place in Sydney $(n=2)$ in 1999 and in Sydney $(n=6)$ and Perth $(n=2)$ in 2001. Both cities have large ethnic Chinese populations and clearly defined areas with concentrations of TCM retailers. Individual retailers were chosen randomly. For semi-structured interviews in 2001 we worked with a Mandarin-speaking Chinese-Australian interpreter. We asked respondents to detail the source, uses, trade routes, volumes and prices of syngnathids they sold and temporal changes in demand or supply. We checked for consistency within an interview by asking for the same information in different ways. Our tallies of TCM retailers and wholesalers for all of Australia were extracted from phone directories and Internet searches.

Our surveys of aquarium retailers stocking seahorses took place in Adelaide $(n=2)$, Sydney $(n=3)$ and Perth $(n=4)$ in 2000 and 2001. We also interviewed aquarium collectors/aquaculturists $(n=6)$. Again, semistructured interviews were used and respondents were asked about the origin and trade routes of seahorses, volumes and prices, and temporal changes in demand and supply. We conducted phone interviews in Sydney $(\mathrm{n}=12)$ and Perth $(\mathrm{n}=8)$ to determine the proportion of aquarium retailers stocking seahorses.

We obtained official export data from 1998 onwards for syngnathids from Environment Australia, including details of the species, source, volume and destination. For 1995-1997 we obtained data on syngnathid exports from the Australian Quarantine and Immigration
Service. We cross-validated Australian export data using official Customs data on syngnathid imports into Hong Kong, mainland China and Taiwan (stated destinations for all dried exports) and the European Union and USA (stated destinations for most live exports). We also compared official export data with estimates from a study of pipehorse bycatch in the Queensland East Coast Trawl Fishery (Connolly et al., 2001).

\section{Data analyses}

All volumes were converted from TCM measuring units into metric units. Prices are given in USD, converted from original units using the mean historical exchange rate for each year. Survey data from 1999 were standardized to 2001 values using changes in exchange rate and adjusting for inflation. Survey data were not normally distributed, with highly skewed data in many cases because of extreme values. We therefore used median values in our calculations, together with $90 \%$ confidence intervals. To estimate yearly domestic consumption of syngnathids we converted weekly sales into yearly values and multiplied these by number of retailers stocking syngnathids and weight or value of each individual. Our range was calculated using the lower and upper confidence intervals for each value. Given the uncertainty associated with each value and the multiple variables associated with each estimate, confidence intervals are large.

For exports of dried syngnathids from Australia we assumed that all of the unclassified exports ('syngnathids') prior to 1998 (and identification to species) were pipehorses, Solegnathus spp., as these represented the overwhelming majority of later exports. To estimate the value of the export fishery we multiplied the mean volume of pipehorses with an estimate of wholesale price provided by fisheries processors (R. Connolly, pers. comm.). We also calculated the mean value of imports to Hong Kong and Taiwan from declared import values. Exports of live seahorses from Australia were analysed separately for the periods 1994-1999 and 2000-2003 because of an order of magnitude change in volumes. Median prices from US Fish and Wildlife Service records were used to estimate the value of the seahorse trade. For other syngnathids (predominantly sea dragons), the only available dataset was the export database of Environment Australia. Median values for these live exports were obtained from Pogonoski et al. (2002) and an interview with an aquarium wholesaler.

\section{Results}

Species, uses, and trade routes to and from Australia

At least 16 species of syngnathid were observed for sale in Australia, dried for TCM or curios or live for the home 
Table 2 Syngnathid species (Table 1) involved in international trade to and from Australia.

\begin{tabular}{|c|c|c|c|c|}
\hline & \multicolumn{2}{|c|}{ Species observed for sale in Australia ${ }^{1}$} & \multicolumn{2}{|c|}{ Species exported from Australia ${ }^{2}$} \\
\hline & Dried & Live & Dried & Live \\
\hline Seahorses & $\begin{array}{l}\text { H. abdominalis }(\mathrm{A}, \mathrm{C}), H \text {. } \\
\text { barbouri/H. hystrix } \\
\text { complex }(\mathrm{O}), H . \text { comes } \\
(\mathrm{O}), \text { H. hystrix }(\mathrm{O}), H . \\
\text { spinosissimus }(\mathrm{O})\end{array}$ & $\begin{array}{l}\text { H. abdominalis }(\mathrm{A}, \mathrm{C}), \text { H. barbouri } \\
\quad(\mathrm{O}, \mathrm{C}), \text { H. breviceps }(\mathrm{A}, \mathrm{C}), \text { H. kuda } \\
\quad(\mathrm{O}, \mathrm{C}), \text { H. reidi }(\mathrm{O}) \text { H. subelongatus } \\
(\mathrm{A}, \mathrm{C}), \text { H. whitei }(\mathrm{A})\end{array}$ & $\begin{array}{l}\text { H. abdominalis } \\
(\mathrm{W}, \mathrm{C})\end{array}$ & $\begin{array}{l}\text { H. abdominalis (W,C), H. angustus } \\
\text { (W), H. breviceps (W,C), H. kuda } \\
\text { (C), H. subelongatus (W,C), H. } \\
\text { whitei (C) }\end{array}$ \\
\hline Seadragons & & P. taeniolatus (A) & & $\begin{array}{l}\text { P. eques }(\mathrm{W}, \mathrm{G}) \text {, } \\
\quad \text { P. taeniolatus }(\mathrm{W}, \mathrm{G})\end{array}$ \\
\hline Pipehorses & $\begin{array}{l}\text { S. hardwickii }(\mathrm{A}) \text {, } \\
\text { S. spinosissimus }(\mathrm{A}, \mathrm{O})\end{array}$ & & $\begin{array}{l}\text { S. dunckeri }(\mathrm{W}), \\
\text { S hardwickii }(\mathrm{W}), \\
\text { S. spinosissimus }(\mathrm{W})\end{array}$ & \\
\hline Pipefish & S. biaculeatus $(\mathrm{O})$ & $\begin{array}{l}\text { Corythoichthys sp. (O), } \\
\text { Doryrhamphus sp. (O), } \\
\text { Vanacampus sp. (A) }\end{array}$ & & $\begin{array}{l}\text { H. nocturna }(\mathrm{W}), \text { S. argus }(\mathrm{W}), \text { S. } \\
\text { cristatus }(\mathrm{W}), \text { V. margaritifer }(\mathrm{W}) \text {, } \\
\text { V. phillipi }(\mathrm{W})\end{array}$ \\
\hline
\end{tabular}

${ }^{1}$ Probable source based on species' distributions is indicated in parentheses. A, Australia, $\mathrm{O}$, other countries. C indicates that some seahorses were reportedly sourced from captive breeding operations in Australia.

${ }^{2}$ Source is indicated in parentheses from information provided in permit returns to Environment Australia. W, wild caught, C, captive-bred, $\mathrm{G}$, grow-out. Captive-bred indicates that progeny can be produced from $\mathrm{F}_{2}$ generations or higher, whereas grow-out refers to rearing of juveniles born to wild-caught adults.

aquarium trade (Table 2). The majority of these dried syngnathids were sourced from outside Australia whereas live syngnathids were from a mixture of domestic and international sources. All respondents reported that their dried syngnathids were imported primarily from Hong Kong, a major distribution and re-export centre. They did not know the countries of origin of the syngnathids. Similarly, most aquarium retailers did not know, or were not willing to disclose, the countries of origin of live syngnathids, except for those produced by Australian captive-breeding operations.

Respondents $(n=7)$ in TCM shops indicated that seahorses, pipehorses and pipefishes were used in the same ways: for 'kidney' (a general term for whole body health; May \& Tomoda, 2002), skin health, for 'men's spirit' (aphrodisiac), as a treatment for asthma \& phlegm, and as a tonic and to clear toxins from blood. In addition, syngnathids were considered a natural remedy that was more efficacious than synthetic drugs. TCM pharmacists surveyed said that syngnathids were invariably sold to ethnic Chinese, usually to fill TCM practitioners' prescriptions $(n=5)$.

Sixteen species of syngnathid were exported from Australia, three only as dried product for the TCM market, 12 as live fishes for the aquarium trade and one species for both trades (Table 2). All dried syngnathids were exported to mainland China, Hong Kong or Taiwan whereas live syngnathids were exported to the European Union, Japan and USA. Reports of 'sea dragons' in TCM refer to the pipehorses Solegnathus spp.; the two Australian sea dragon species (Phycodurus eques and Phyllopteryx taeniolatus) are neither exported nor used in TCM (Vincent, 1996; AV, pers. obs).

\section{Estimated syngnathid imports into Australia and domestic trade}

All TCM retailers reported that dried seahorses were expensive items and that trade volumes were variable but generally low. Dried pipehorses were considered to be too expensive for the local market and were rarely sold. Dried pipefishes were cheaper items and were usually included in the same prescriptions as seahorses. Overall, our estimates of Australian consumption of dried syngnathids were minor, both in volume and value (Table 3).

Live seahorses were sold throughout Australia, apparently as popular items, but we estimate that relatively few individuals were actually traded although their high unit value meant that the value of the trade was reasonably large (Table 3). We did not obtain any estimates of volumes or values of other live syngnathids traded in Australia.

\section{Estimated syngnathid exports from Australia}

Most dried syngnathids exported from Australia were pipehorses. Early exports were labelled only as syngnathids, but species identity was recorded from 1998, revealing that $>98 \%$ of all later exports, at least, were the pipehorses $S$. dunckeri or S. hardwickii (Fig. 1). All recorded pipehorse exports were sourced from bycatch in the Queensland East Coast Trawl Fishery. Australian export data showed considerable temporal fluctuations in pipehorse exports, with an average of about $1 \mathrm{t}$ per annum (Fig. 1, Table 4). The only declared exports of 
Table 3 Domestic trade in syngnathids in Australia.

\begin{tabular}{|c|c|c|c|c|c|c|c|}
\hline Species & $\begin{array}{l}\text { Number of } \\
\text { retailers } \\
\text { interviewed }\end{array}$ & $\begin{array}{l}\text { Median } \\
\text { number } \\
\text { sold wk }{ }^{-1} \\
\text { (range) }\end{array}$ & $\begin{array}{l}\text { Median weight } \\
\text { (g) per individual } \\
\text { (range) }\end{array}$ & $\begin{array}{l}\text { Median price } \\
\text { (USD) per } \\
\text { individual in } \\
2001 \text { (range) }\end{array}$ & $\begin{array}{l}\text { Estimated total } \\
\text { number of retailers } \\
\text { stocking syngnathids } \\
\text { (range) }\end{array}$ & $\begin{array}{l}\text { Estimated } \\
\text { total volume } \\
\times 10^{3} \mathrm{~kg} \mathrm{yr}^{-1}\end{array}$ & $\begin{array}{l}\text { Estimated } \\
\text { total value } \\
\times 10^{3} \mathrm{USD} \\
\mathrm{yr}^{-1}\end{array}$ \\
\hline \multicolumn{8}{|l|}{ Dried trade } \\
\hline \multicolumn{8}{|l|}{$\begin{array}{l}\text { Seahorses, } \\
\text { Hippocampus }\end{array}$} \\
\hline spp. & 10 & $6(2-20)$ & $3(2-4)$ & $1.5(1.0-2.5)$ & $63(45-85)$ & $59(9-350)$ & $29(5-221)$ \\
\hline S. biaculeatus & 10 & $6(2-20)$ & $1.0(0.8-1.3)$ & $0.3(0.2-0.5)$ & $63(45-85)$ & $20(3-115)$ & $6(1-44)$ \\
\hline \multicolumn{8}{|c|}{ Live trade } \\
\hline $\begin{array}{l}\text { Seahorses, } \\
\text { Hippocampus }\end{array}$ & & & & & & & \\
\hline spp. & 9 & $5(2-10)$ & - & $11(9-18)$ & $47(36-57)$ & $12.2(3.7-29.6)$ & $134(34-530)$ \\
\hline
\end{tabular}

All dried syngnathids

S. dunckeri - Hong Kong

S. hardwickii - Hong Kong
S. hardwickii - China

D.

S. dunckeri - Taiwan

S. hardwickii - Taiwan



Fig. 1 Records of dried pipehorses Solegnathus spp. exported by Australia over 1995-2001. Prior to 1998 syngnathids were not taxonomically differentiated and may have included some seahorses. Source: Environment Australia. dried seahorses were about $5 \mathrm{~kg}$ of $H$. abdominalis from aquaculture operations in 1998 and another $10 \mathrm{~kg}$ in 2001.

Australia's export data for syngnathids differed considerably from Hong Kong's import data, both in terms of declared species and volumes. Hong Kong recorded large imports of dried seahorses from Australia in some years (Fig. 2), although Taiwan reported none in its long time series of data (since at least 1982). The volumes of pipehorses imported to Hong Kong from Australia (Fig. 3) were always greater than those recorded in Australian export statistics to Hong Kong. Taiwanese import data (Fig. 3) were more consistent with Australian export data except during 2001 (cf. Figs 1 \& 3). Calculated volumes of pipehorses exported from Australian seafood processors in June-December 1999 were 632, and $837 \mathrm{~kg}$ for 2000 (Connolly et al., 2001), consistent with Hong Kong and Taiwan's import data rather than with Australia's export data. Declared values for seahorses in Hong Kong declined sharply from 1998 (the first year of record keeping) to 1999 and thereafter remained stable, whereas pipehorses showed the opposite trend, rising from 1998 to 1999 and then remaining stable (Fig. 3). Conversely, in Taiwan, the value of pipehorses generally declined slightly over 1994-2001 (Fig. 3). The overall value of the pipehorse fishery was considerable despite large annual fluctuations (Table 4).

Records of trade of live seahorses from Australia in the period 1994-1999 were consistently low using either 
Table 4 Summary of volumes and values for international exports of dried syngnathids from Australia derived from official customs data. Sources: Environment Australia, Hong Kong Census and Statistics Department, Republic of China (Taiwan) Customs Statistics.

\begin{tabular}{|c|c|c|c|c|c|c|c|c|c|}
\hline \multirow[b]{2}{*}{ Species } & \multicolumn{3}{|c|}{ Australian export data } & \multicolumn{3}{|c|}{ Hong Kong import data } & \multicolumn{3}{|c|}{ Taiwan import data } \\
\hline & $\begin{array}{l}\text { Period } \\
\text { covered }\end{array}$ & $\begin{array}{l}\text { Mean volume } \\
\mathrm{kg} \mathrm{yr}^{-1} \pm \mathrm{SD}\end{array}$ & $\begin{array}{l}\text { Estimated value } \\
(\text { range }) \times 10^{3} \\
{\text { USD } \mathrm{yr}^{-1}}\end{array}$ & $\begin{array}{l}\text { Period } \\
\text { covered }\end{array}$ & $\begin{array}{l}\text { Mean } \\
\text { volume kg } \\
\mathrm{yr}^{-1} \pm \mathrm{SD}\end{array}$ & $\begin{array}{l}\text { Mean value } \\
\times 10^{3} \mathrm{USD} \\
\mathrm{yr}^{-1} \pm \mathrm{SD}\end{array}$ & $\begin{array}{l}\text { Period } \\
\text { covered }\end{array}$ & $\begin{array}{l}\text { Mean } \\
\text { volume kg } \\
\mathrm{yr}^{-1} \pm \mathrm{SD}\end{array}$ & $\begin{array}{l}\text { Mean value } \\
\times 10^{3} \mathrm{USD} \\
\mathrm{yr}^{-1} \pm \mathrm{SD}\end{array}$ \\
\hline \multicolumn{10}{|c|}{$\begin{array}{l}\text { Seahorses, } \\
\text { Hippocampus }\end{array}$} \\
\hline $\begin{array}{l}\text { spp. } \\
\text { Pipehorses, } \\
\text { Solegnathus }\end{array}$ & 1998-2001 & $4 \pm 5$ & & 1998-2002 & $153 \pm 103$ & $27 \pm 35$ & 1995-2002 & 0 & 0 \\
\hline spp. & 1995-2001 & $1,010 \pm 770$ & $131(71-192)^{1}$ & 1998-2002 & $870 \pm 480$ & $121 \pm 42$ & 1995-2002 & $470 \pm 340$ & $42 \pm 31$ \\
\hline
\end{tabular}

${ }^{1}$ As there were no declared values for Australian export data these values have been calculated using the mean exported volume and the range of wholesale prices paid to processors in 1999-2000 of USD 70-190 kg-1 (R. Connolly, pers. comm.).

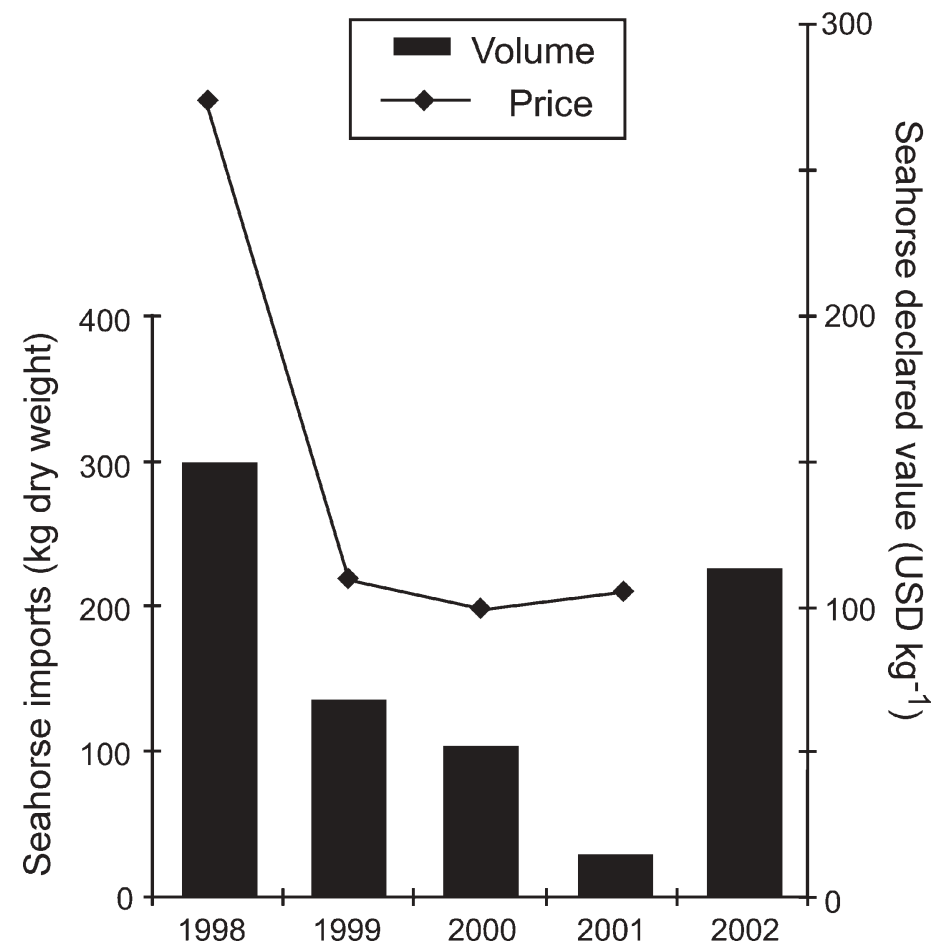

Fig. 2 Official Customs records of dried seahorse Hippocampus spp. imports into Hong Kong from Australia 1998-2002. Source: Hong Kong Census and Statistics Department. export or import data (Fig. 4). An order of magnitude increase in exports occurred in 2000. This was attributed almost entirely to captive-bred H. abdominalis in Environment Australia records, although USA import records classified almost half of the seahorses as wild-caught. Export and import data showed congruent patterns although export volumes were always $20-100 \%$ higher (Fig. 4). The estimated value of the live seahorse trade was relatively minor (Table 5). Export records for other syngnathids, almost exclusively the two sea dragon species, showed a reasonably constant, low volume trade over the period 1994-2001 (Fig. 5). Despite this low volume the trade was lucrative (Table 5).

\section{Discussion}

Our data provide the first quantitative estimates of the scale of Australian trade in syngnathids. In general, trade in syngnathids to and from Australia was relatively minor, particularly in comparison with trade involving China, Hong Kong, India, Indonesia, Mexico, Taiwan, Thailand and Vietnam (Vincent, 1996; Giles et al., 2005; A. Vincent \& A. Perry, unpubl. data). However, Australia is clearly the major source of dried pipehorses and sole source of live sea dragons for international trade, despite the uncertain quality of some data.

Survey data involved extrapolating from limited numbers of interviews to countrywide estimates of 

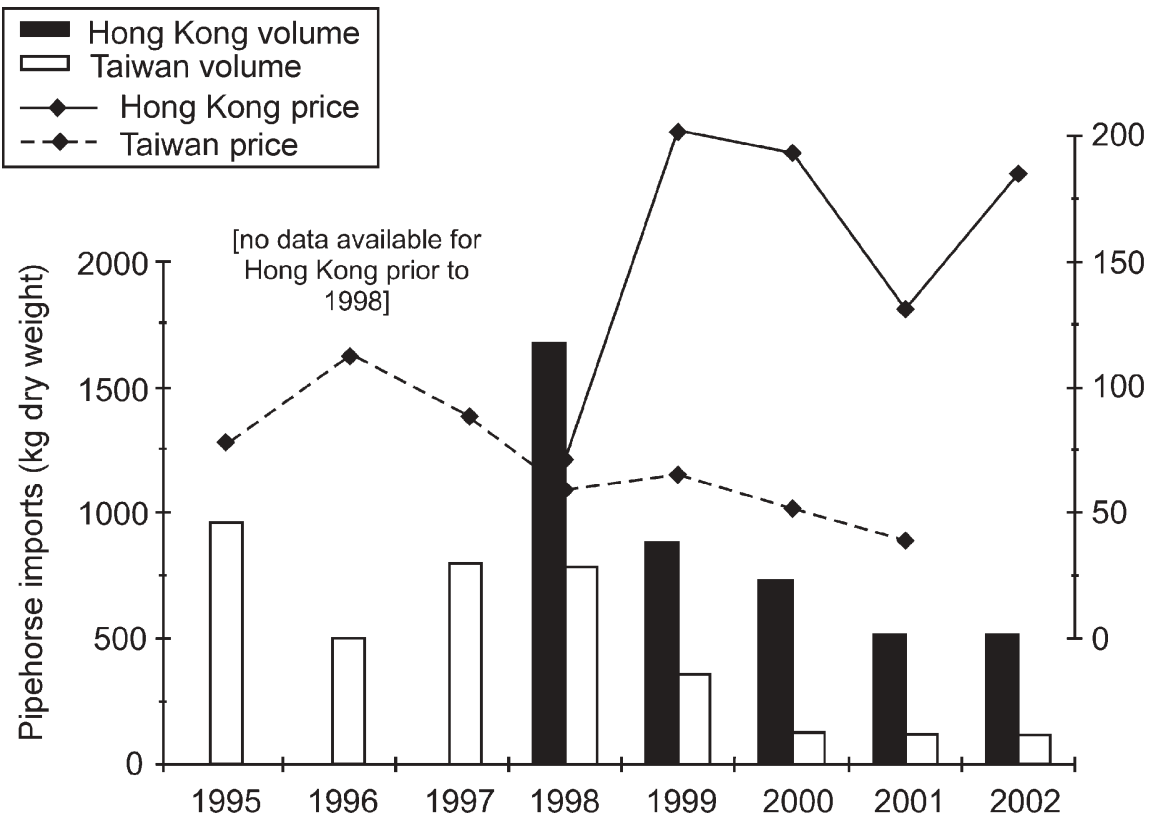

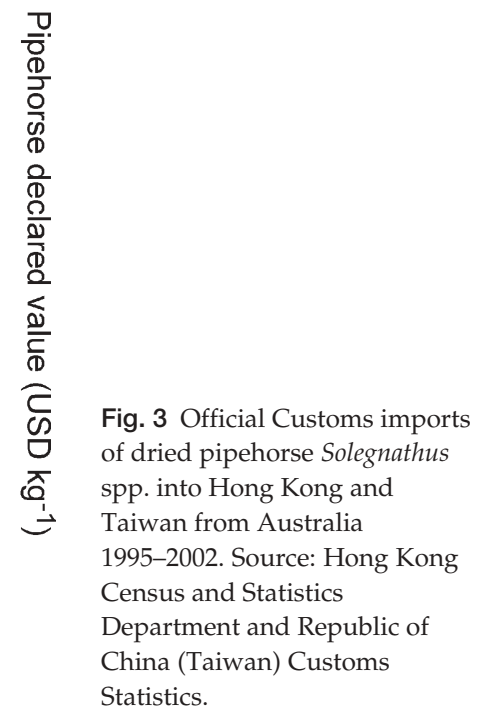

Statistics. consumption, raising questions about the representativeness and transparency of our respondents. Within the limits of our logistic constraints, we controlled for these concerns with random sampling and internal validation techniques, and cross-verified using multiple data sets wherever possible. Similar techniques in Hong Kong produced quantitative estimates that were substantiated when official Customs data became available from 1998, with no evidence of exaggeration (Vincent, 1996).

The limited official data still allowed clear inferences, whatever their flaws. Despite mandatory reporting since 1998, Australian syngnathid export figures differed considerably from import statistics to Hong Kong, the most important export destination. Discrepancies in volumes of dried seahorses moving from Australia to Hong Kong are probably best explained as misidentification/ mistranslation of pipehorse imports as seahorses in Hong Kong. However, the large discrepancies between export and import data sets for pipehorses (up to fivefold in 1999 and 2000) suggest that these Australian exports may have been significantly under-reported, especially as interviewed pipefish processors produced data agreeing closely with import figures from Hong Kong and Taiwan (Connolly et al., 2001).

\section{Pipehorse and sea dragon trade}

The trade in dried pipehorses had considerable economic and conservation significance, representing the largest syngnathid trade from Australia. As pipehorses are only landed as bycatch, they may provide an economic subsidy to the fishery, thus promoting fishing effort (Hall et al., 2000). Import data from Hong Kong and Taiwan showed declines in pipehorse volumes over 1998-2002. Such changes may arise from overexploitation, spatial and temporal redistribution of fishing effort, altered demand for (or value of) pipehorses, or alternative sourcing. Catches of pipehorses in Queensland declined over 1998-2000 (Connolly et al., 2001), but a dearth of data on the distribution of fishing effort and on wild populations precludes interpretation. To determine whether current rates of exploitation are sustainable, fisheries-independent data should be collected for pipehorse populations along with accurate catch and effort statistics from the trawl fisheries. Biological research is also needed. Pipehorses, like many other syngnathids, occur at low population densities (Connolly et al., 2001). Local depletions may render them vulnerable to Allee effects wherein reproduction is reduced through the inability of reproductively capable animals to find a mate (Gascoigne \& Lipcius, 2004).

The aquarium fishery for sea dragons is also economically important, primarily because individual animals are valuable. However, this trade represented only a limited catch of wild sea dragons. The practice of catching a few brooding males and rearing the young for later sale means that the trade is almost certainly sustainable, particularly for the widespread P. taeniolatus. Both sea dragon species have been considered to show no evidence of population declines (Pogonoski et al., 2002).

\section{Seahorse trade and aquaculture}

The seahorse fishery (including aquaculture) is probably of limited economic importance throughout Australia. Total fisheries production (including aquaculture) from 
(A) Australian exports

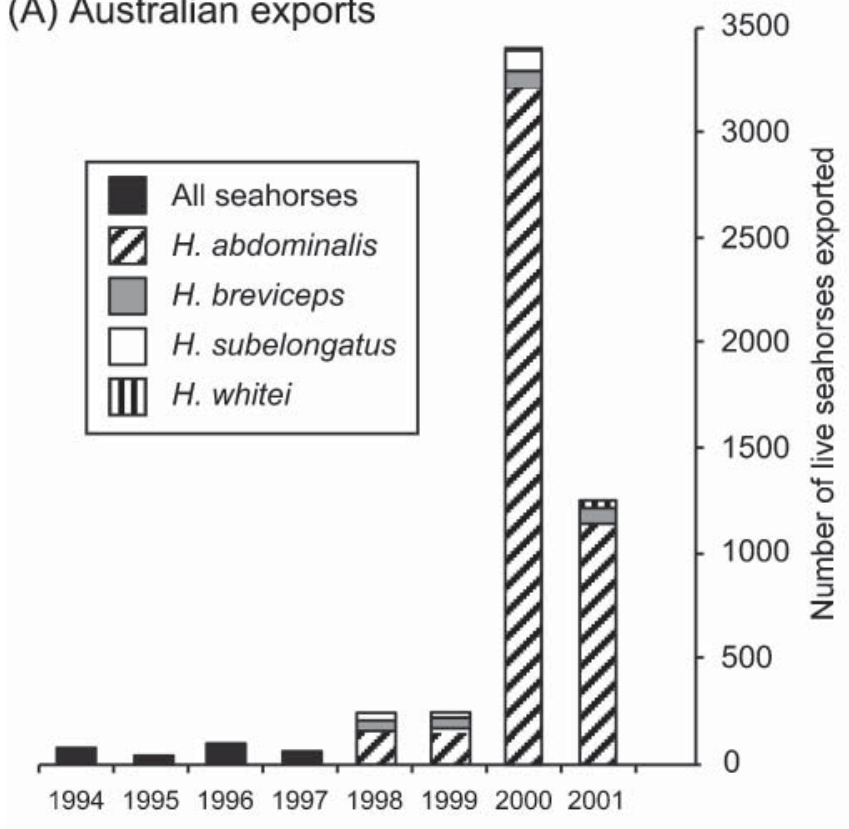

\section{(B) European \& USA imports}

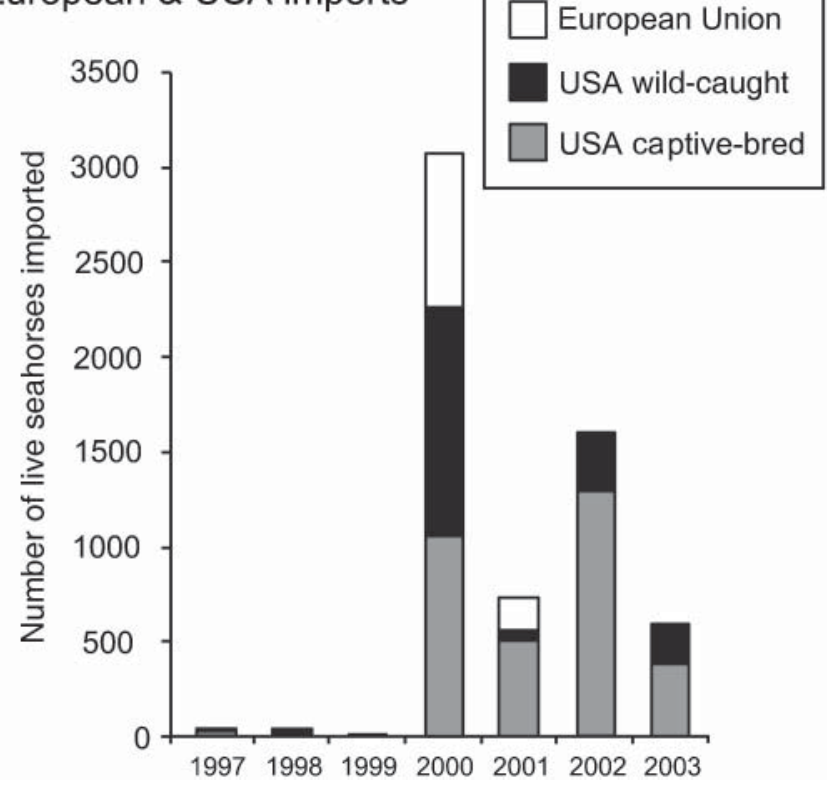

Fig. 4 Live seahorses exported by Australia. (A) Export data from 1994-2001 with species differentiation only from 1998. Source: Environment Australia. (B) Import data from the USA from 1997-2003 and EU from 1997-2001. Sources: US Fish and Wildlife Service, UNEP-WCMC CITES trade database.
Australia was estimated to have a gross value of USD 1.4 billion in 2002-3 (Caton, 2003). Thus, seahorses, at most, represented between $0.001-0.01 \%$ of total gross fisheries revenue. Unlike neighbouring south-east Asia, seahorses are not caught in large numbers in Australian coastal fisheries, either targeted or as bycatch (Stobutzki et al., 2001). Thus, international trade does not appear to pose a major threat to seahorse populations.

Seahorse aquaculture developed substantially in Australia over 1996-2001. Following increased awareness of a market for seahorses a number of start-up aquaculture ventures were proposed throughout Australia. In 2004 at least four operations were culturing seahorses commercially for the domestic aquarium market.

Seahorse aquaculture may increase pressures on wild populations. Broodstock for aquaculture is taken from the wild, initially for start up and then to preclude inbreeding depression, but the effects of such removal have not been quantitatively monitored. Seahorse aquaculture often involves obtaining wild food supplies and discharging potentially contaminated wastewater. The business nature of seahorse aquaculture in Australia creates a pressure to sell as many animals as possible, sometimes for new uses and/or to countries that did not 
Table 5 Estimated volumes and values for international exports of live syngnathids from Australia derived from official customs data, where available. Sources: Environment Australia, UNEP-WCMC CITES trade database, US Fish and Wildlife Service.

\begin{tabular}{|c|c|c|c|c|c|c|}
\hline \multirow[b]{2}{*}{ Species } & \multicolumn{3}{|c|}{ Australian export data } & \multicolumn{3}{|c|}{ USA \& EU import data } \\
\hline & $\begin{array}{l}\text { Period } \\
\text { covered }\end{array}$ & $\begin{array}{l}\text { Mean volume } \\
\text { individuals } \\
\mathrm{yr}^{-1} \pm \mathrm{SD}\end{array}$ & $\begin{array}{l}\text { Estimated value } \\
(\text { range }) \times 10^{3} \mathrm{USD} \\
\mathrm{yr}^{-1}\end{array}$ & $\begin{array}{l}\text { Period } \\
\text { covered }\end{array}$ & $\begin{array}{l}\text { Mean volume } \\
\text { individuals } \\
\mathrm{yr}^{-1} \pm \mathrm{SD}\end{array}$ & $\begin{array}{l}\text { Estimated value } \\
(\text { range }) \times 10^{3} \mathrm{USD}_{\mathrm{yr}}\end{array}$ \\
\hline Seahorses, & 1994-1999 & $132 \pm 95$ & $5(3-25)$ & 1997-1999 & $27 \pm 19$ & $1(0.7-5)$ \\
\hline Hippocampus spp. & 2000-2001 & 2340 & $18(12-23)$ & 1999-2003 & $1,800 \pm 1190$ & $14(9-18)$ \\
\hline P. eques & 1994-2001 & $49 \pm 31$ & $\begin{array}{c}6(3-10)^{1} \\
45(25-64)^{2}\end{array}$ & & & \\
\hline P. taeniolatus & 1994-2001 & $155 \pm 84$ & $\begin{array}{l}20(8-31)^{1} \\
60(40-81)^{2}\end{array}$ & & & \\
\hline Others (pipefish species) & 1994-2001 & $11 \pm 31$ & & & & \\
\hline
\end{tabular}

${ }^{1}$ Estimates from values given in Pogonoski et al. (2002)

${ }^{2}$ Estimates from an interview with an aquarium wholesaler.

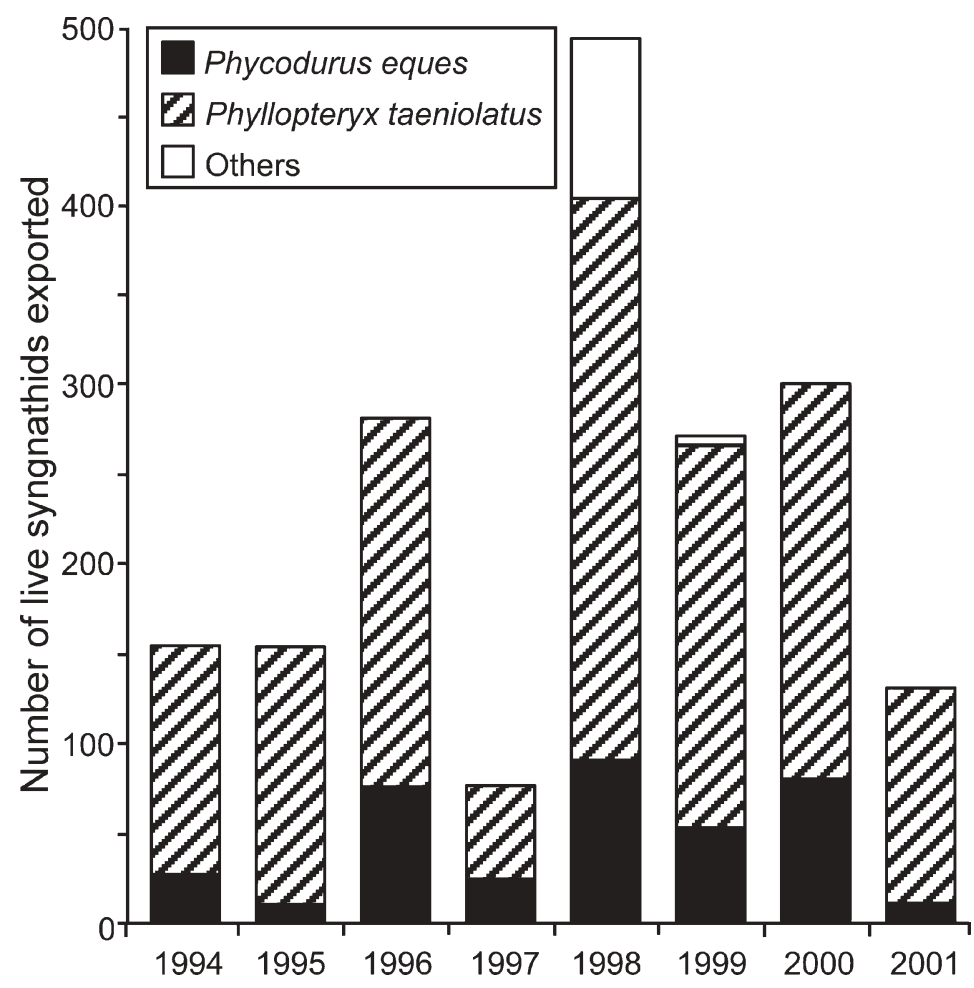

Fig. 5 Export records of live seadragons, Phyllopterx taeniolatus and Phycodurus eques, and pipefish species from Australia for 1994-2001. Source: Environment Australia. trade in seahorses historically. If such new demand cannot be supplied solely from aquaculture or can be supplied more cheaply from elsewhere, pressure on wild populations will increase. Seahorse aquaculture will only have positive benefits for wild seahorses if demand remains relatively constant and switches from wild to cultured animals, raised in operations that are environmentally sound. If demand simply increases to match increased supply, no net conservation benefit will be achieved.

\section{Other threats to syngnathids}

Overall, habitat loss and degradation are probably the greatest conservation concerns for Australian coastal species, including syngnathids (Australia SoE Committee, 2001). Degradation of estuaries and coastal lakes, declines in temperate seagrasses, loss of mangroves and salt marshes, unsustainable coastal development, effects of fishing, introductions of foreign organisms and population increases in native species (Drupella snails and crown-of-thorns starfish Ananthaster planci) all pose 
problems (Australia SoE Committee, 2001). MartinSmith \& Vincent (2005) found large declines in seahorse H. abdominalis populations in the Derwent estuary, Tasmania, unrelated to fishing pressure. Similar population declines have been suggested for both $H$. dahli in Moreton Bay, Queensland and H. subelongatus in the Swan River, Western Australia (Johnson, 1999; Pogonoski et al., 2002). Verco's pipefish Vanacampus vercoi was identified as being particularly vulnerable to habitat loss, disturbance or alteration because of its restricted geographical range in South Australia and its apparent preference for shallow (2-3 m depth) habitats (Pogonoski et al., 2001).

\section{Using syngnathids as conservation flagships}

Australia is committed to syngnathid conservation in particular and marine conservation in general. Considerable public awareness and appreciation of syngnathids has fostered strong community involvement in marine issues. Moreover, Australia's legal framework for fisheries and conservation should help ensure long-term persistence of seahorse populations, assuming proper enforcement. Its role may be particularly important for species whose populations elsewhere in the Indo-Pacific are being overexploited to meet trade demands.

Australia's Oceans Policy was launched in 1998, with specific commitments to accelerate development and management of marine protected areas, support mandatory water quality standards and increase understanding of commercial and recreational impacts on marine habitats (Commonwealth of Australia, 1998). Similarly, State governments have had policies in place to prevent further degradation or restore habitat, including the establishment of representative marine protected areas. Non-governmental organizations and government agencies are involved in many projects ranging from habitat restoration through stormwater treatment to marine protected areas. These initiatives need to be supported through judicious engagement with particular species that are representative of general problems, such as pipehorse bycatch in indiscriminate gear. In this respect, we would hope for cooperation with New Zealand, where pipehorse bycatch remains unmonitored. Syngnathids have the potential to act as powerful icons for sustainable trade in marine products.

\section{Acknowledgements}

This is a contribution from Project Seahorse. We thank all stakeholders, agencies and organizations who shared information with us, and colleagues who provided ideas and data, acted as translators or gave us constructive comments, including Daniel Bowles, Rod Connolly,
Sarah Foster, Brian Giles, Alan Kendrick, Angela McCue, Bob Bern Ming Wong, Craig Woodfield and two anonymous referees. We appreciate generous financial support from the Community Fund, UK, Guylian Chocolates, Belgium, and British Airways. Additional valuable help came from the John G. Shedd Aquarium, USA, through its partnership for marine conservation with Project Seahorse.

\section{References}

Adams, M.B., Powell, M.D. \& Purser, G.J. (2001) Effect of acute and chronic ammonia and nitrite exposure on oxygen consumption and growth of juvenile big bellied seahorse. Journal of Fish Biology, 58, 848-860.

Australia State of the Environment Committee (2001) Australia State of the Environment 2001. Independent Report to the Commonwealth Minister for the Environment and Heritage. CSIRO Publishing on behalf of the Department of the Environment and Heritage, Canberra, Australia.

Caton, A.E. (ed.) (2003) Fishery Status Reports 2002-2003: Assessments of the Status of Fish Stocks Managed by the Australian Government. Bureau of Rural Sciences, Canberra, Australia.

Commonwealth of Australia (1998) Australia's Oceans Policy. Environment Australia, Canberra, Australia.

Connolly, R.M., Cronin, E.R. \& Thomas, B.E. (2001) Trawl Bycatch of Syngnathids in Queensland: Catch Rates, Distribution and Population Biology of Solegnathus Pipehorses (Seadragons). Fisheries Research and Development Corporation Report 1999/124, Canberra, Australia.

Dawson, C.E. (1985) Indo-Pacific Pipefishes (Red Sea to the Americas). The Gulf Coast Research Laboratory, Ocean City, USA.

DragonSearch (2005) http:/ / www.dragonsearch.asn.au / [accessed 3 November 2005].

Foster, S.J. \& Vincent, A.C.J. (2004) Life history and ecology of seahorses: implications for conservation and management. Journal of Fish Biology, 65, 1-61.

Gascoigne, J. \& Lipcius, R.N. (2004) Allee effects in marine systems. Marine Ecology - Progress Series, 269, 49-59.

Giles, B.G., Truong Si Ky, Do Huu Hoang \& Vincent, A.C.J. (2005) The catch and trade of seahorses in Vietnam. Biodiversity and Conservation. Biological Conservation, in press.

Hall, M.A., Alverson, D.L. \& Metuzals, K.I. (2000) By-catch: problems and solutions. Marine Pollution Bulletin, 41, 204-219.

IMCRA (Interim Marine and Coastal Regionalisation for Australia Technical Group) (1998) Interim Marine and Coastal Regionalisation for Australia: An Ecosystem-based Classification for Marine and Coastal Environments. Version 3.3. Environment Australia, Commonwealth Department of the Environment, Canberra, Australia.

IUCN (1994) 1994 Categories and Criteria (version 2.3). IUCN, Gland, Switzerland [http:/ / www.redlist.org/info/ categories_criteria1994.html, accessed 3 November 2005].

IUCN (2001) 2001 Categories and Criteria (version 3.1). IUCN, Gland, Switzerland [http://www.redlist.org/info/ categories_criteria2001.html, accessed 3 November 2005].

IUCN (2004) IUCN Red List of Threatened Species. IUCN, Gland, Switzerland [http:/ / www.redlist.org, accessed 21 June 2004]. 
Johnson, J.W. (1999) Annotated checklist of the fishes of Moreton Bay, Queensland, Australia. Memoirs of the Queensland Museum, 43, 709-762.

Kendrick, A.J. \& Hyndes, G.A. (2003) Patterns in the abundance and size-distribution of syngnathid fishes among habitats in a seagrass-dominated marine environment. Estuarine, Coastal and Shelf Science, 56, 1-10.

Kuiter, R.H. (2000) Seahorses, Pipefishes \& Their Relatives. A Guide to the Syngnathiformes. T.M.C. Publishing, London, UK.

Kuiter, R.H. (2003) A new pygmy seahorse (Pisces: Syngnathidae: Hippocampus) from Lord Howe Island. Records of the Australian Museum, 55, 113-116.

Lourie, S.A., Vincent, A.C.J. \& Hall, H.J. (1999) Seahorses: An Identification Guide to the World's Species and their Conservation. Project Seahorse, London, UK.

Martin-Smith, K.M. \& Vincent, A.C.J. (2005) Seahorse declines in the Derwent estuary, Tasmania in the absence of fishing pressure. Biological Conservation, 123, 533-545.

May, B. \& Tomoda, T. (2002) Seahorses in the Ben cao gang $m u$ and in contemporary Chinese medicine. Journal of the Australian Chinese Medicine Education \& Research Council, $L t d$., March 2002, 2-12.

Payne, M.F. \& Rippingale, R.J. (2000) Rearing West Australian seahorse, Hippocampus subelongatus, juveniles on copepod nauplii and enriched Artemia. Aquaculture, 188, 353-361.

Payne, M.F., Rippingale, R.J. \& Longmore, R.B. (1998) Growth and survival of juvenile pipefish (Stigmatopora argus) fed live copepods with high and low HUFA content. Aquaculture, 167, 237-245.

Pogonoski, J.J., Pollard, D.A. \& Paxton, J.R. (2002) Conservation Overview and Action Plan for Threatened and Potentially Threatened Marine and Estuarine Fishes. Environment
Australia, Department of Environment and Heritage, Canberra, Australia.

Steffe, A.S., Westoby, M. \& Bell, J.D. (1989) Habitat selection and diet in two species of pipefish from seagrass: sex differences. Marine Ecology - Progress Series, 55, 23-30.

Stobutzki, I.C., Miller, M.J., Jones, P. \& Salini, J.P. (2001) Bycatch diversity and variability in a tropical penaeid fishery: the implications for monitoring. Fisheries Research, 53, 283-301.

Takahashi, E., Connolly, R.C. \& Lee, S.Y. (2003) Growth and reproduction of double-ended pipefish, Syngnathoides biaculeatus, in Moreton Bay, Queensland, Australia. Environmental Biology of Fishes, 67, 23-33.

Vincent, A.C.J. (1996) The International Trade in Seahorses. TRAFFIC International, Cambridge, UK

\section{Biographical sketches}

Keith Martin-Smith works on a diverse range of projects involving syngnathid fishes. He is particularly interested in the effects of bycatch on rare species, the ecosystem role of syngnathids and the influence of artificial structures in the marine environment on population dynamics of seahorses.

Amanda Vincent's early research on seahorse ecology has led to broad initiatives in conservation science, management and policy, often featuring seahorses. She holds the Canada Research Chair in Marine Conservation, and is Director of Project Seahorse, an interdisciplinary group working to advance marine conservation. 